\title{
Leitura, escrita e educação
}

https://doi.org/10.34112/2317-0972a2019v37n76pg-10

\section{ANderson Ricardo Trevisan ${ }^{1}$}

Renata Aliaga ${ }^{2}$

O ARTigo de Abertura Desta edição da Revista Leitura: Teoria \& Prática trata de assunto de suma relevância: a importância da memória para a consolidação das práticas de leitura. Para isso, o professor André Luiz Paulilo, da Faculdade de Educação da Unicamp, parte dos princípios teóricos de Gerard Namer, de um lado e, de outro, das afirmações de Fernando de Azevedo e Maria Reis Campos acerca do papel do livro na atividade docente. Em tempos em que se nota um movimento de negação da história e da ciência em setores da sociedade que deveriam defendê-las, nada mais relevante do que destacar a importância dos livros e da memória para a educação. Aliás, as ciências e o saber associados à leitura aparecem também nos artigos de Adair Adams e Jonathan Henriques do Amaral, que abordam as possibilidades de uso da literatura como recurso pedagógico no ensino de Filosofia e Sociologia, e de Maria José P. M. de Almeida e Érica Talita Brugliato, que discutem o ensino de Ciências a partir de trabalhos dos Encontros Nacionais de Pesquisa em Educação em Ciências (ENPECs), de 2011 a 2017.

A formação de leitores é o assunto de três outros artigos deste número. O primeiro, escrito por Amanda Hermann e Heloisa Sisla, busca identificar a presença da

1. Universidade Estadual de Campinas, Campinas, SP, Brasil.

2. Instituto Federal de São Paulo, Campinas, SP, Brasil. 
consciência fonológica no processo de alfabetização, tendo como um dos resultados a percepção de sua rejeição no processo de alfabetização por determinados setores. O segundo artigo, de Márcia Regina Rodrigues Ferreira e Patrícia Veronesi Batista, procura analisar pesquisas recentes que relacionam os conceitos de formação de leitores ao contexto da sociedade da informação, destacando ações que podem contribuir para a formação de competências nos leitores. $\mathrm{O}$ tema reaparece no artigo de Elaine Braz e Sandra Guimarães, agora relacionado às práticas docentes do ensino fundamental no que tange ao ensino da compreensão da leitura, cujos resultados apontam para uma necessidade de aprimoramento dessa prática, que muitas vezes se limita à compreensão literal das informações veiculadas pelos textos.

Os dois últimos artigos que apresentamos tratam da produção literária de crianças, seja oral ou escrita. Em seu artigo, Karin Cozer Campos discute como o texto literário pode contribuir para potencializar a produção narrativa oral das crianças no ambiente escolar. Tailane Antunes e Edilaine Buin Barbosa, por sua vez, destacam a atividade de recontextualização como parte essencial da produção textual de estudantes do Ensino Médio em uma escola pública estadual, no município de Dourados (MS). O trabalho realizado pelos estudantes, uma nova versão de Chapeuzinho Vermelho, apontou que a materialidade dos contos recontextualizados pelos estudantes revela experiências tanto empíricas quanto simbólicas e marca ideologias, crenças e valores. Como conclusão, as autoras destacam que a atividade de recontextualização parece contribuir de forma relevante para o desenvolvimento da escrita.

Por fim, esta edição traz a resenha escrita por Daniela Molina sobre o livro do argentino Alberto Manguel, O Leitor como metáfora (o viajante, a torre, e a traça) (São Paulo, SP: Edições SESC, 2017), que apresenta um panorama da história da leitura.

Como vemos, este número de LTP, em sua diversidade de temas, confirma, por um lado, o sentido plural de leitura e de escrita que nos move e, por outro, reitera algo que é central para todos nós: a centralidade da educação. Todos os artigos, de uma forma ou outra, discutem a papel do docente na formação de escritores ou leitores. Em uma época em que essa profissão - e a educação, num sentido amplo - sofrem tantos ataques, é fundamental que continuemos a realizar esse trabalho de valorização da atividade docente na formação de sujeitos críticos e conscientes. 